\title{
人工内耳症例の言語聴取能の長期経過
}

\author{
新谷 朋子・承見 徹夫 \\ 吉岡旅・形浦 昭克
}

\section{Speech Perception in Patients with Nucleus Cochlear Implant}

\author{
Tomoko Shintani, Tetsuo Himi, Iwao Yoshioka and Akikatsu Kataura \\ (Medical University School of Medicine)
}

The 22-channel cochlear implant was placed in 12 postlingual profoundly deaf patients since 1988. Psychological, physical, and speech functioning were investigated in 7 of the 12 patients, one year or more after surgery. The threshold level and maximum comfort level showed minimal changes even 4 years after first programming. The number of applicable electrodes (mean value, 17) was stable for over one year. Speech perception with and without lipreading was examined 3 months, 1 year and 4 years after first programming. Without lipreading, correct responses in the vowel test (mean, 67.1\%) were better than in the consonant test (mean, 31.3\%). Speech tracking scores with lipreading (18.5 phrases/min.) were considerably high for regular speech perception, and 3 of the 5 patients tested more than 4 years after surgery had excellent speech tracking scores (29 phrases/min.), which seemed to be very close to those with normal hearing. The other 2 patients did not use their cochlear implant systems much because of their limited social activity. It is concluded that the routine use of the implant system and/or adequate personal social activity are probably important factors in attaining acute speech perception.

Key words: cochlear implant, speech perception, postlingual deaf

\section{はじめに}

メルボルン大学の Clark らが開発した人工内 耳は, 襲・高度感音性難聴の患者に対して聴神 経を直接刺激することによって音感覚を引き起 こし聴力を回復させるもので世界的にはすでに 広く応用されている人工藏器である1). 日本で は1985年に舩坂 ${ }^{2)}$ が第 1 例目の人工内耳手術を 施行以来, 200名以上の難聴者が手術を受け, 良好な聴取能が得られていることが報告されて いる. 術後のリハビリテーションにより徐々に 自然な聞こえに近づくことは，ヒトの高次言語
中枢の適応能力, 優れた補経能力によるものと 考えられている314). しかし，日本語を言語と する人工内耳の長期使用例はまだ 9 年程度と長 期使用者の絶対数はまだ少ないといら点，また 現在人工内耳の埋め込及術が盛んに行われてい る現状を考えると長期装用による言語聴取能の 向上を経時的に捉えることは今後のリハビリ テーションプログラムを考学る上で重要である と考学る．このことより，今回われわれは当科 の人工内耳症例の中でも比較的長期に装用して いる症例を選び，これらの症例の経時的な聴取 
能変化について検討したので報告する.

\section{対象および方法}

1988年より1994年までに当科にて人工内耳手 術(22チャンネル人工内耳，コクレア社)を受け た 12 症例のらち, 術後 1 年以上経過した 7 名の 患者を対象とした(表 1 )。装用状況は表 1 に示 した如く，5例は日常的に使用し 2 例の使用頻 度は他に比し低かった。症例 $1 \sim 3,6,7$ は外 出の機会が多いなど生活に積極性が見られ，起 床時から就眠まで，または就労期間中，人工内 耳を使用していた。一方, 症例 4, 5 は術後 1 , 2 年経過した頃より全く人工内耳を使用せず, リハビリテーション時に使用するのみであった。

検討した項目は以下のごとくである.

1. 使用電極数, $\mathrm{T}$ レベル(最小可聴域値), Cレベル(最大快適域值), ダイナミックレンジ の平均值, 聴取能に関しては母音・子音・文章 の聴取能の变化を検討した。評価時期は音入れ 直後， 3 力月， 1 年， 4 年後とした.

2 . 同一検者による肉声でのテストは，母音； /i/, /e/, /a/, /o/, /u/をランダムに 6 回ずつ 提示し, 子音; $/ \mathrm{a} /+/ \mathrm{pa}, \mathrm{ta}, \mathrm{ka}, \mathrm{ba}, \mathrm{da}, \mathrm{ga}$, za, ha, sa, ma, na, ra, ja, wa/をランダムに 4 回ずつ提示しそれぞれの聴取能を評価した。 文章の聴取能評価は, 小学校高学年程度の文章 を 5 分間読み，正しく聞き取った文節数(/分)
につき評価した。評価時期は同様に音入れ直後, 3 力月, 1 年, 4 年後とした.

3. 4 年以上の長期使用例の 3 症例について は，国立身体障害者リハビリテーションセン ター；福田友美子氏制作のビデオを用いた聴取 能の評価を, 単音 $(50$ 語), 単語 (50単語), さら に文章 (基礎単語からなる $2 \sim 6$ 文節の文章)に つき行った。

\section{結果}

1. 現在の使用電極数, $\mathrm{T}, \mathrm{C} レ$ ベルおよび ダイナミックレンジの平均は表 2 に示した. 電 極の挿入は十分と考兄られたが，6名の患者で は手術後 1 年で音が響くため正円空側の電極が $2 \sim 3$ 本使用できず，現在の使用電極数は平均 17 対であった．経時的な閾値の変化は 4 年以上 の長期使用例に扮いても大さな変化はなく良好 な電極の使用状況が見られた。症例 4,5 はダ イナミックレンジが術直後より 30 デジタルュニ ット以下と狭く, 症例 4 では使用電極が15対と 少なかった。

2. 経時的聴取能の変化

（1）母音の聴取能 : 人工内耳のみ(図 1 ) では 音入れ直後は平均 $43.4 \%$ であるが， 1 年後は平 均 $67.1 \%$ と聴取能が向上している.ささらに 4 年 経過した症例では平均 $82.0 \%$ であった。 人工内 耳十読話では 7 名とも $100 \%$ 理解可能であった。

表 1 対 象

\begin{tabular}{|c|c|c|c|c|c|c|c|}
\hline 患者 & 職業 & 年齢 & 失聴原因 & 失聴期間 & 手術日 & 装用期間 & 装用状況 \\
\hline 症例 1 女 & & 44 & 進行性感音性難聴 & 5年 & 88年 4月 & 5年 11 力月 & 毎日 \\
\hline 症例 2 女 & & 52 & ストマイ使用 & 22年 & 88年12月 & 5年 2力月 & 毎日 \\
\hline 症例 3 女 & & 55 & 進行性感音性難聴 & 2年 & 89年 1月 & 5年 1カ月 & 毎日 \\
\hline 症例 4 男 & & 63 & ストマイ使用 & 37年 & 89年11月 & 4年 3カ月 & $\begin{array}{l}\text { ほとんど } \\
\text { 使用せず }\end{array}$ \\
\hline 症例 5 女 & & 69 & ストマイ使用 & 20年 & 89年12月 & 3年 2 力月 & $\begin{array}{l}\text { ほとんど } \\
\text { 使用せず }\end{array}$ \\
\hline 症例 6 女 & & 21 & 餚膜炎 & 13年 & 91年 7月 & 2年 7カ月 & 毎日 \\
\hline 症例 7 男 & & 61 & 蹃膜炎 & 2年 & 92年 7月 & 1 年 7カ月 & 毎日 \\
\hline
\end{tabular}


（2）子音の聴取能 : 人工内耳のみ(図 2-a)で は 1 年後では平均 $31.3 \%$ の聴取能であったが, 4 年を経過した症例では平均 $51.3 \%$ であった。 人工内耳+読話(図 $2-b$ ) では 1 年後では平均 $78.9 \%, 4$ 年後では平均 $94.0 \%$ の聴取能であっ た。

（3）文章の聴取能 (Speech Tracking test) : 人工内耳のみ (図 $3-\mathrm{a}$ ) では 1 年後の聴取能が
5.9文節/分であるが，読話を併用（図 3-b)で は18.5文節/分であった。 4 年を経過した症例 では平均 29.0 文節/分で，注湆健聴者と同程度 (30〜 40文節/分)の聴取能であった.

3. ビデオを用いた聴取能の評価(表 3 )

単音節の検査では人工内耳のみでは 4 年後で も平均 $12.6 \%$ の聴取能であった．読話を併用す ると平均 $44.7 \%$ であり, 症例 1 では $70 \%$ 以上の

表 2 現在の使用電極数, T, C レベルおよびダイナミックレンジの平均值

\begin{tabular}{c|ccccc}
\hline \hline & 使用機種 & $\begin{array}{c}\text { 使用電極数 } \\
\text { (対) }\end{array}$ & $\begin{array}{c}\text { 平均T-レベル } \\
\text { (d.u.) }\end{array}$ & $\begin{array}{c}\text { 平均C-レベル } \\
\text { (d.u.) }\end{array}$ & $\begin{array}{c}\text { 平均 } \\
\text { ダイナミック } \\
\text { レンジ (d.u.) }\end{array}$ \\
\hline 症例 1 & MSP & 17 & 95 & 157 & 62 \\
症例 2 & MSP & 19 & 95 & 163 & 58 \\
症例 3 & MSP & 17 & 62 & 124 & 63 \\
症例 4 & MSP & 15 & 104 & 130 & 30 \\
症例 5 & WSP & 20 & 139 & 161 & 20 \\
症例 6 & MSP & 17 & 65 & 144 & 78 \\
症例 7 & MSP & 18 & 89 & 173 & 84 \\
\hline
\end{tabular}

d.u. ; デジタルユニット

刺激モード;BP+1.

$\mathrm{F}_{0} / \mathrm{F}_{1} / \mathrm{F}_{2}$ strategy

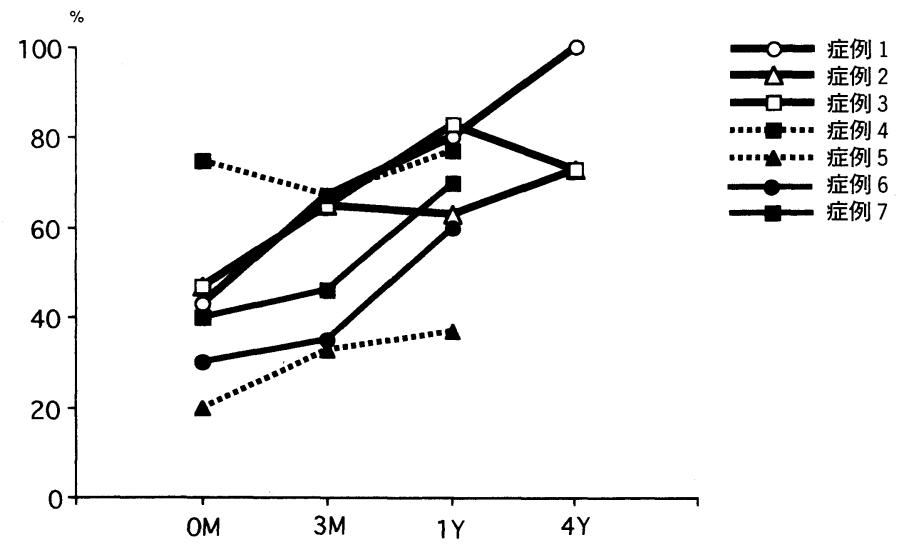

図 1 母音(人工内耳のみ)

音入れ直後は平均 $43.4 \%$ であるが 1 年後は $67.1 \%$ で特に 4 年以上 の症例では平均 $82.0 \%$ と向上が見られた. 
聴取能を示したが，肉声による短音節に比し低 值を示した。単語聴取能は人工内耳のみでは 1 年後では平均 $10.7 \%$ であるが， 4 年後ではその
平均 $32.3 \%$ であった。 しかし，読話を併用にて も 1 年後, 4 年後とも平均 $42.0 \%$ の聴取結果で あり，著明な聴取能の向上は見られなかった。

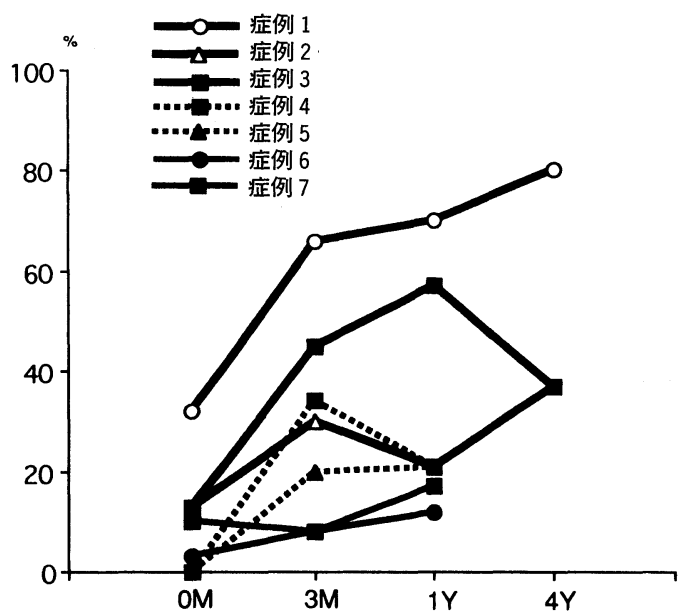

a

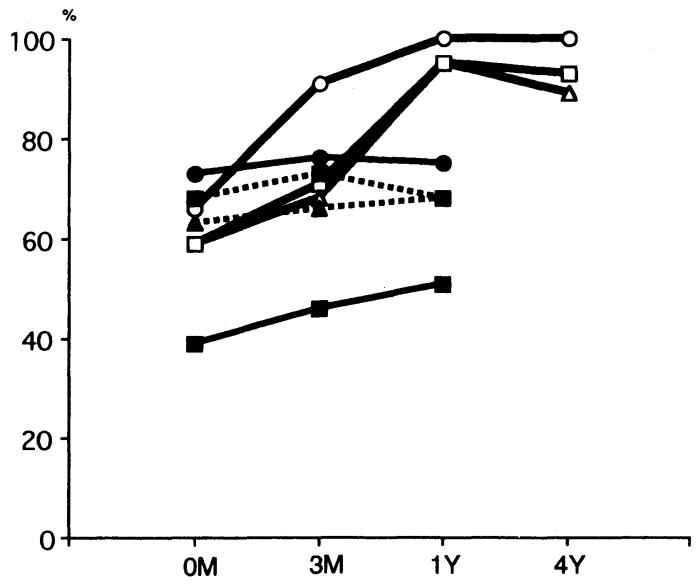

$\mathrm{b}$

図 2 (a )子音 (人工内耳のみ)

1 年後では平均 $31.3 \%$ であったが 4 年後では平均 $51.3 \%$ であった.

(b) 子音 (人工内耳十読話)

1 年後では平均 $78.9 \%, 4$ 年後では $94.0 \%$ の聴取能であった.

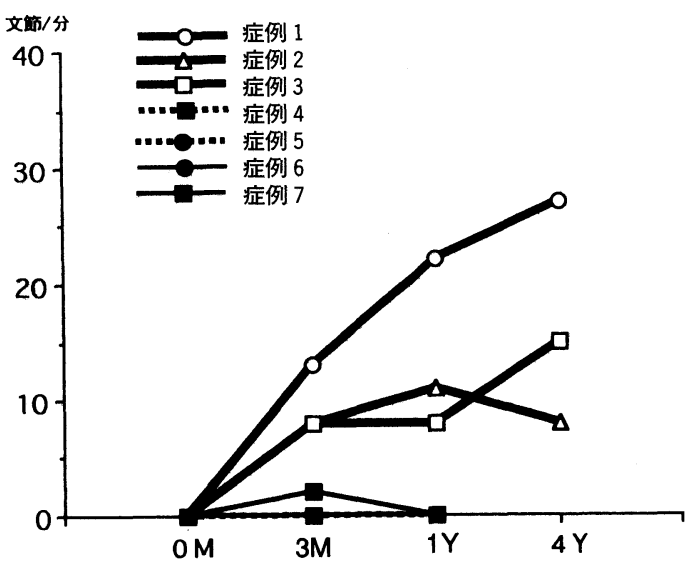

a

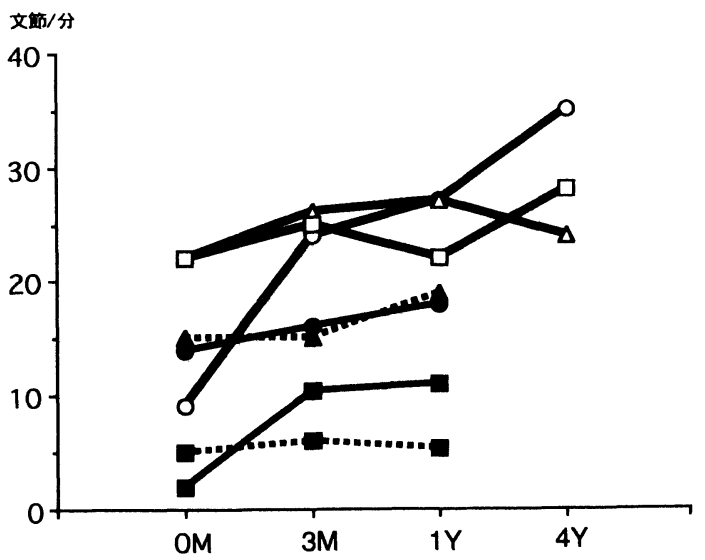

b

図 3（a )文章の聴取能 (人工内耳のみ)

実線; 日常装用者, 点線; 非日常装用者で示したが, 日常装用者では経過と ともに聴取能の向上が見られた.

(b ) 文章の聴取能 (人工内耳十読話)

4 年以上経過した日常装用者では健聴者と同程度の聴取能が得られていた. 
また，文章による検査では，人工内耳のみでは 1 年後に比し 4 年後には全例に聴取能の向上が 見られ(平均 $24.3 \%$ )，読話併用では 4 年後では 平均 $58.6 \%$ の理解が可能であったが，人工内耳 のみの検査核どの向上は見られなかった.

\section{考察}

人工内耳は生涯装用する症例が洼とんどと考 えられる．この意味では人工内耳手術直後に発 生する問題から，長期装用にともない発生する 問題点に的確に対処していくことが必要となる. 初期の問題としては, 電極の挿入不可, 術後の めまい, コイル部の不快感, 耳鳴, 耳漏, 顔面 痤攣，電極の位置の移動などが本邦でも報告さ れている5) 7). さらに長期留置による安全性, 副作用の有無が問題となる. 実験的には電極挿 入の際に多少のライスネル膜, ラセン神経節の 損傷が見られることはあるが neural population の有意な減少はないと報告されている8 ${ }^{8}$.

人工内耳はことばの聴取の面のみでなく，患 者の日常生活の質の変化をもたらし，心理面， 精神面でも大きく貢献している. 多くの症例で は環境音の聴取も可能となるため，術前の狭い 行動範囲が術後には著明に拡大し, 社会性が増 大するといら利点が見られることは言らまでも
ない、しかし，人工内耳本来の治療目的につい ての最も大きな問題点は，会話の聴取能が満足 なレベルに達しない症例の見られることである。 実際に1993年に人工内耳の使用者がまとめた報 告書でもほとんどの患者は手術を受けたことに 満足しているが，聞こえの内容に関する不満が 多いことがわかる9).

コクレア社製人工内耳は母音の聴取能は良く, 大橋らの報告10)では $22 \mathrm{ch}$. の人工内耳患者で は母音の正当率は $85 \%$ に達しているが，子音に ついては正当率が約 $50 \%$ ととどまると指摘して いる. 自験例でも 1 年後の聴取能は人工内耳の みでは母音; 平均 $67.1 \%$, 子音 ; $31.3 \%$ だが読 話の併用では母音は全員 $100 \%$ 理解が可能であ った。この理由として子音の音声特質が関与し ていると考兄られ，子音の特徵である子音過渡 部分のエネルギーが著しく弱く，また波形変化 も著しく速いため，人工内耳のスピーチプロセ ッサーでは実時間処理による分析が十分できな いと考壳られている，さらに子音は一連の音素 としてではなく，脳内での照合，おそらくは short term memory 内での子音の弁別的特徵か ら判定されるものであるからではないか，と述 ベている10111.

表 3 ビデオを用いた評価による手術後 4 年以上経過した症例の聴取能の変化

\begin{tabular}{|c|c|c|c|c|c|c|c|}
\hline & \multicolumn{2}{|c|}{ 単音（\%） } & \multicolumn{2}{|c|}{ 単語（\%） } & \multicolumn{2}{|c|}{ 文章 $(\%)$} \\
\hline & & 人工内耳のみ & 人工内耳+読話 & 人工内耳のみ & 人工内耳+読話 & 人工内耳のみ & 人工内耳+読話 \\
\hline \multirow{2}{*}{ 症例 1} & 1 年後 & 20 & 42 & 22 & 70 & 24 & 78 \\
\hline & 4 年後 & 24 & 70 & 18 & 48 & 48 & 79 \\
\hline \multirow{2}{*}{ 症例 2} & 1 年後 & 4 & 8 & 8 & 36 & 3 & 57 \\
\hline & 4 年後 & 0 & 18 & 18 & 38 & 18 & 53 \\
\hline \multirow{2}{*}{ 症例 3} & 1 年後 & 8 & 38 & 2 & 20 & 0 & 44 \\
\hline & 4 年後 & 14 & 32 & 24 & 40 & 7 & 44 \\
\hline
\end{tabular}


しかし，文章聴取能に関して，舩坂らにによ れば言語には日本語，外国語を問わず圥長性が あり，人工内耳患者では約 $50 \%$ 聞き取れれば意 味は理解でき，ややゆっくり話された会話では 100\%完全聴取できると述べている．自験例で も文章聴取能は読話を併用すると 1 年後では泀 添正常に近いスピードで聴取が可能であった。

一方，ビデオを用いた聴取能は不良であったが， これは聞き慣れない検査者であること，機械を 通した音声であるためであると思われる。人工 内耳使用者はテレビや電話などの音声は聞きつ らいと述べて扣り，ビデオでの評価は難しいと 思われるが，自宅でのリハビリテーションの一 環としてビデオを使用することは有用と考学ら れる。

言語聴取能の優劣に関与する因子としては, 術前検查としてのプロモントリーテスト（岬角 電気刺激検查)の結果，失聴時年齢，失聴期間， 原因疾患，使用電極数， Tレベル， Cレベルさ らにダイナミックレンジなどが関与すると考学 られているが12)我々の症例では数がまだ少な く比較することは難しかった. 船坂 2 ), 伊藤ら ${ }^{13)}$ の報告によればプロモントリーテストについて は反応があれば聴神経の残存が期待できるいわ ば定性試験であり，術後の言語聴取能を予測す るものではないとされる．原因疾患については 進行性難聴, 䯣膜炎が聴取能が良く, メニエー 儿病は不良であるとする報告がある14)が，我 々の症例では必ずしも一致しなかった，術後の 言語理解が術前に予測できれば術前の患者への 説明，手術への同意を得るのに非常に有用であ るが，現時点ではこの目的に合致する確定的な 術前検査結果括よび患者側の要因はないと考光 られている11)15)

埋め込及後の電気生理学的検査では, 子音の 明瞭度の良好な条件として1）Tレベルが低い， 2 )使用電極数が多い，3 ) ダイナミックレンジ が広いことが考觉られている，Tレベルは電流 刺激に対する感度特性と考えられて扣り，Tレ ベルが低いことは内耳に残存する神経末端の高
い感受性を意味し，電極数が多ければ周波数分 解能が向上するため, 子音の聴取能も向上する と考えられている15).

また，電極数に関する Holmes ら ${ }^{16)}$ の検討 では，電極数が 15 対以上だと会話能力が向上す るとされるが，合成母音検査を用いた理論的検 討では，人工内耳患者での母音聴取率は，挿入 電極数が関与し, 電極間距離が離れる程, 異聴 率は低くなり，さらにF2 より F1 での異聴が より少ない傾向が見られたことより，電極はで きる限り蝸牛頂に近づけるように深く挿入し, 22本全て挿入することが望ましいと結論してい る10).

前述のように術後の言語理解を術前に予測し らる確定的な術前検査結果括よび患者側の要因 はなく，我々の症例でも多くは音入れ後聴取能 の良否がはっきりするのが現状であるが，今回 検討した患者のうち 4 年以上日常使用している 症例では，時間の経過とともに聴取能の向上が 見られた．このことから，術直後には満足な聴 取能が得られなくとも長期の装用により経時的 な聴取能の向上が期待できる症例が多いと推察 される.一方，日常的に使用していない症例 4 ， 5 は他の症例に比してダイナミックレンジが 狭いものの母音，子音などの聴取能が不良では なかった。しかし, 症例 4 はコイル部の不快感, 異和感に固執しリハビリを嫌がり，人工内耳を 使用しょうとしなかった。主治医と家族は毎日 1 時間でも使用することを勧めたが，そのうち 家族関係が悪くなり，本人の精神的負担となっ ているようなので装着を強要することは控えた。 症例 5 は術後，手足を 3 回骨折したため家にい ることが多く家人との会話は読話で足りていた このように日常生活ではそれぞれ筆談と読話で 困ることがないため人工内耳の必要性を強く感 じない，普段家族以外の人との関わりがないな ぞ生活の活動性に欠けるなどの理由から装用状 況が不良である場合は，これが聴取能の向上を 妨げる要因とも考えられた。城間ら15) も人工 内耳の使用に対する積極性を良好な聴取能の重 
要な要因のひとつとして挙げ，使用時間の長い 患者ほど語音明瞭度が優れている傾向が見られ ることを指摘している.このことは高次機能の 可塑性を考慮すれば十分に理解できる. 今後, 人工内耳の普及が期待されるが，術後の聴取能 向上のためのリハビリテーションについては, 通常プログラムに加えて, 生活の場で長い時間 を使用し，活用するように指導することも重要 なことと推察された。

\section{まとめ}

1. 12 名の人工内耳症例の $5 ち 1$ 年以上装用 の 7 名について電極の状態, 経時的な聴取能の 变化を検討した。

2 . 現在の使用電極数は平均 17 対で，特に 4 年以上の長期使用例 3 名では閾值に大さな変化 はなく良好な電極の使用状況であった。

3. 母音の聴取能は良く, 人工内耳のみでは 平均 $67.1 \%$ であったが，子音は $31.3 \%$ と不良で あった。

4. 文章聴取能は読話を併用で 1 年後には平 均 18.5 文節/分, 4 年以上では 29.0 文節/分とほ ぼ正常に近いスピードで聴取可能であった.

5. 4 年以上日常使用している症例では聴取 能の向上が見られた。良好な聴取能を得る要因 のひとつに使用電極数や電気生理学的な検查に 加觉て, 使用時間, 装用に対する積極性も考兄 られた。

本論文の要旨は第94回日本耳鼻咽喉科学会総会に て発表した。

\section{文献}

1）船坂宗太郎, 本庄 㘎, 形浦昭克, 他 : 30 名の 人工内耳植光込久患者の臨床試験成績. 耳喉頭 頸 $64:$ 149 157, 1992.

2）船坂宗太郎 : 人工内耳 一壟患者への貢献一. 第93回日本耳鼻咽喉科学会総会 宿題報告. 1992.

3）熊川孝三 : 22 チャンネル人工内耳による語音の 音響記憶. 日耳鼻 $94: 1136 \sim 1141,1991$.

4) 本庄 箃：人工内耳の現状と将来. 耳鼻臨床 $86: 1 \sim 11,1993$.
5）城間将江, 湯川久美子, 河野 淳, 他：人工内 耳使用に関する問題と対応. Audiology Japan $36: 415 \sim 416,1993$.

6）伊藤壽一, 榊原淳二, 高木 明, 他 : 人工内耳 手術症例の検討 一特に結果が不十分な症例飞 ついて一. 耳鼻臨床 $86: 647 \sim 651,1993$.

7）伊藤壽一, 竹内真理子, 榊原淳二, 他 : 人工内 耳埋め込久手術の現状と問題点.耳鼻臨床 84 : 317 320, 1991.

8) Shephred RK, Clark GM, Pyman BC, et al ; Banded intracochlear electrode array ; evaluation of insertion trauma in human temporal bones. Ann Otol Rhinol Laryngol 94 : 55 59, 1985.

9) 人工内耳友の会 (ACITA) 運営委員会. 122人 からの回答書 人工内耳の実態調査. 1993.

10）大橋伸也：人工内耳患者に扮ける子音聴取能の 分析的研究. 耳展 $36: 572 \sim 581,1993$.

11) Wickelgren WA : Distinctive features and errors in short-term memory for English consonants. J Acoust Soc Am 39 : 388 398, 1933.

12) Blamey PJ, Pyman BC, Gordon M, et al : Factors predicting postoperative sentence scores in postlinguistically deaf adult cochlear implant patients. Ann Otol Rhinol Laryngol $101: 342$ $\sim 348,1992$.

13）伊藤壽一, 高木 明, 本庄 珤, 他: 人工内耳 手術34症例の臨床的評価. 耳鼻臨床 $87: 185 \sim$ 192, 1994.

14）城間将江, 河野 淳, 湯川久美子, 他：人工内 耳50症例の語音聴取成績. Audiology Japan $35: 24 \sim 25,1992$.

15）城間将江, 本多清志, 河野 淳, 他: 人工内耳 装用者の語音聴取能に影響を及ぼす要因. 音声 言語医学 $32: 371 \sim 377,1991$.

16) Holmes AE, Kemker FJ and Merwin GE : The effects of varying the number of cochlear implant electrodes on speech perception. Am J Otol 8 : 240 246, 1987.

$$
\left.\begin{array}{l}
\text { (原稿受付: 平成 } 6 \text { 年 } 4 \text { 月 } 11 \text { 日 } \\
\text { 原稿採択 : 平成 } 6 \text { 年 } 5 \text { 月 } 9 \text { 日 } \\
\text { 別刷請求先 : 新谷朋子 } \\
\text { 干 } 060 \text { 札幌市中央区南 } 1 \text { 条西 } 16 丁 \text { 目 } \\
\text { 札幌医科大学耳鼻咽喉科学教室 }
\end{array}\right)
$$

